\title{
Efficacy of the multimodal strategy for Hand Hygiene compliance: an integrative review
}

\author{
Eficácia da estratégia multimodal para adesão à Higiene das Mãos: revisão integrativa \\ Eficacia de la estrategia multimodal en la adhesión a la Higiene de las Manos: revisión integradora
}

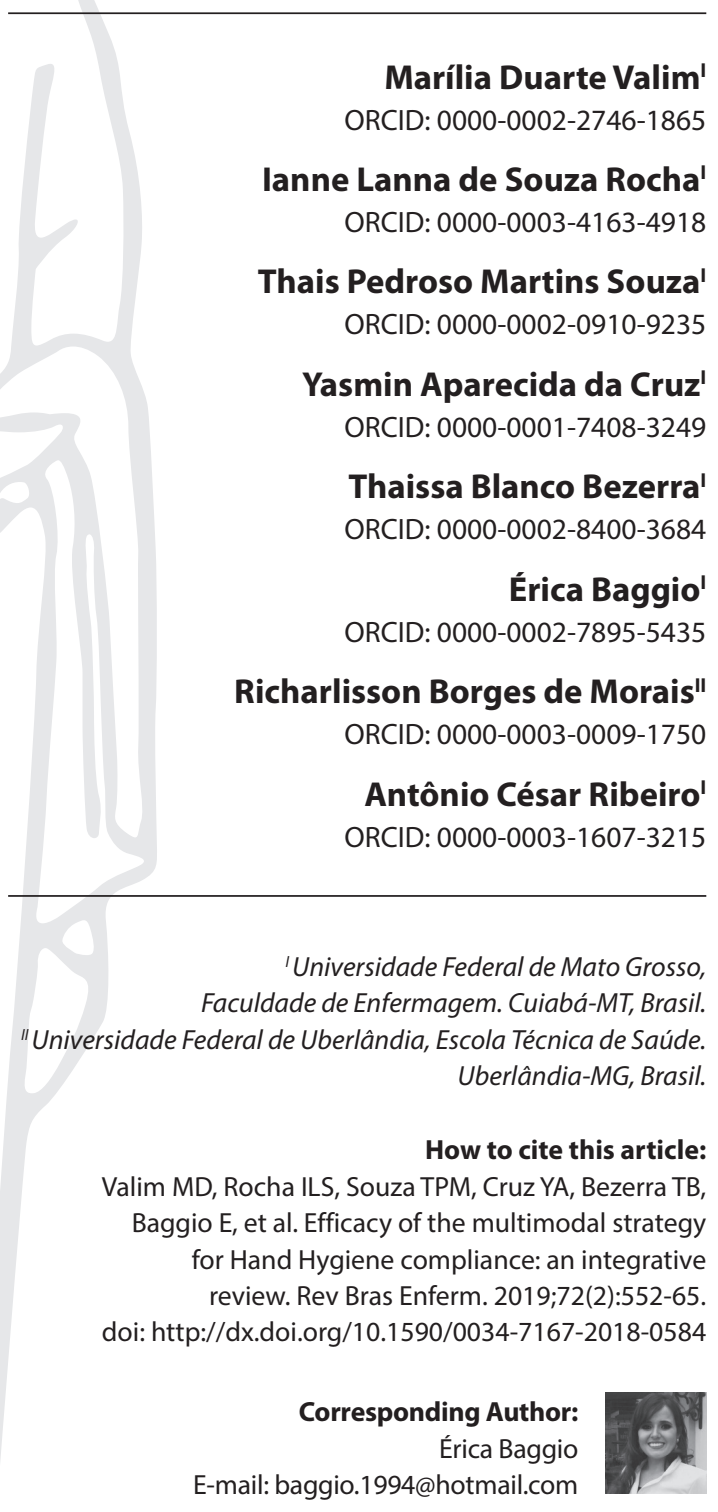

Submission: $05-17-2018$
Approval: 09-01-2018

\section{ABSTRACT}

Objective: Evaluate, from the literature, the effectiveness of the implementation of the multimodal strategy for health professionals compliance with Hand Hygiene and its sustainability over time. Method: Integrative review, with a view to answering the following question: "Is the implementation of the multimodal strategy effective in health professionals compliance with Hand Hygiene and can it be sustained over time?". The MEDLINE, SCOPUS, LILACS and CINAHL databases were used to retrieve the primary articles. Results: Twenty-five studies were analyzed. Among the components of the multimodal strategy, three need to be better worked: health education, feedback from practices and management involvement. Although it needs to focus more on its five elements, interventions based on the multimodal strategy have favored $\mathrm{HH}$ compliance and its long-term sustainability. Conclusion: The strategy proved to be effective for $\mathrm{HH}$ compliance, especially when all integrating components are adequately addressed. Descriptors: Hand Hygiene; Cross Infection; Personnel Health; Patient Safety; Health Knowledge, Attitudes, Practice.

\section{RESUMO}

Objetivo: Avaliar, a partir da literatura, a eficácia da implementação da estratégia multimodal para adesão dos profissionais de saúde à Higiene das Mãos e sua sustentabilidade ao longo do tempo. Método: Revisão integrativa, com vistas a responder a seguinte questão: "A implementação da estratégia multimodal é eficaz na adesão dos profissionais de saúde à Higiene das Mãos e pode ser sustentada ao longo do tempo?". Utilizaram-se as bases de dados MEDLINE, SCOPUS, LILACS e CINAHL para recuperar os artigos primários. Resultados: Foram analisados 25 estudos. Dentre os componentes da estratégia multimodal, três precisam ser melhor trabalhados: educação em saúde, feedback de práticas e envolvimento da gestão. Embora necessite maior enfoque dos seus cinco elementos, as intervenções baseadas na estratégia multimodal favoreceram a adesão à $\mathrm{HM}$ e sua sustentabilidade em longo prazo. Conclusão: $\mathrm{A}$ estratégia se mostrou eficaz para adesão à $\mathrm{HM}$, em especial, quando todos componentes integradores são adequadamente contemplados.

Descritores: Higiene das Mãos; Infecção Hospitalar; Pessoal de Saúde; Segurança do Paciente; Conhecimentos, Atitudes e Prática em Saúde.

\section{RESUMEN}

Objetivo: Evaluar, a partir de la literatura, la eficacia de la implementación de la estrategia multimodal en la adhesión de los profesionales de salud a la Higiene de las Manos y su sostenibilidad a lo largo del tiempo. Método: Revisión integradora, para responder a la siguiente pregunta: “¿La implementación de la estrategia multimodal es eficaz en la adhesión de los profesionales de la salud a la Higiene de las Manos y puede ser sostenida a lo largo del tiempo?" Se utilizaron las bases de datos MEDLINE, SCOPUS, LILCAS y CINAHL para recuperar los artículos primarios. Resultados: Se analizaron 25 estudios. Entre los componentes de la estrategia multimodal, tres necesitan ser mejor trabajados: educación en salud, feedback de prácticas e involucramiento de la gestión. Aunque necesite un mayor enfoque de sus cinco elementos, las intervenciones basadas en la estrategia multimodal favorecieron la adhesión a la HM y su sostenibilidad a largo plazo. Conclusión: La estrategia se mostró eficaz en la adhesión a la HM, en particular cuando todos los componentes integradores están adecuadamente contemplados. Descriptores: Higiene de las Manos; Infección Hospitalaria; Personal de Salud; Seguridad del Paciente; Conocimientos, Actitudes y Práctica en Salud. 


\section{INTRODUCTION}

Health Care-Related Infections (HCAl) represent a global challenge for patient safety. In recent years, greater concern has been expressed by health agencies and institutions to control and prevent the risk of such infections and at the same time to improve and ensure safe and quality care ${ }^{(1-2)}$. Currently, they are considered a serious public health problem, as it affects millions of people, increasing morbidity and mortality, increasing antimicrobial resistance and excessive spending for health systems that could be preventable by basic precautionary measures, Hand Hygiene $(\mathrm{HH})^{(1,3)}$.

Since 2005, the World Health Organization (WHO) has been adopting some strategies to be used in order to prevent the risks inherent to HCAI. In 2009, the multimodal strategy was recognized and disseminated internationally to improve compliance with $\mathrm{HH}$ practices, since hand washing is the simplest, most cost-effective and least costly measure to minimize the spread of pathogens and thus control and prevent the HCAl ${ }^{(1-2)}$. The multimodal strategy prioritizes five key components that favor the change of practices and behaviors, namely: change in the system, which is related to the infrastructure of the institution; education and training of health professionals; evaluation and feedback of Hand Hygiene; reminders in the workplace and favorable institutional security environment ${ }^{(1)}$.

Recent research has demonstrated the importance of promoting adequate $\mathrm{HH}$ technique compliance among health professionals in order to reduce the high rates of infections caused by multidrug resistant microorganisms ${ }^{(4-9)}$. However, low compliance with these practices remains a challenge for practitioners and health institutions, especially in developing countries, which may present an HCAI rate up to 20 times higher than in developed countries ${ }^{(10)}$.

In Brazil, the rates of compliance with registered $\mathrm{HH}$ remain below the recommended level, with an average of $50 \%$ compliance in the health institutions investigated ${ }^{(11)}$. The reasons for low compliance have multifaceted characteristics, which are related from the physical structure and support existing in the institution, available material and human resources, to professional behavior, conditioned, among others, to the process of education ${ }^{(11-12)}$.

In this context, the multimodal strategy has been encouraged by several health agencies worldwide as a complete tool to achieve satisfactory results, since only the educational training does not guarantee the continuous improvement of $\mathrm{HH}$ practice ${ }^{(8)}$. Accordingly, the active participation of the heads and managers of the institutions was also highlighted, since the valuation of the change to maintain the favorable security environment can be considered effective for the change and maintenance of the indexes of improvement of $\mathrm{HH}$ compliance throughout the time ${ }^{(9,13)}$.

It is emphasized that efficacy in the context of health can be defined as the promotion of services widely available to all who can benefit, through scientific knowledge, to avoid both underutilization and excessive use of technologies ${ }^{(14)}$. Thus, the multimodal strategy is considered effective when, after its implementation in health institutions, it increases the $\mathrm{HH}$ compliance by health professionals and remains sustained over time ${ }^{(1-3)}$.

\section{OBJECTIVE}

This study aims to evaluate, from the literature, the effectiveness of the implementation of the multimodal strategy for health professionals compliance with Hand Hygiene and its sustainability over time.

\section{METHOD}

It is an integrative review of the literature, which proposes the synthesis of the results of previous studies on the same subject ${ }^{(15)}$. The integrative reviews have been highlighted in the area of Nursing in the last decade and this is due to its broad potential on specific subjects, which allows the nurses who are in clinical practice to perform nursing care based on scientific evidence ${ }^{(16)}$.

For the development of the same, six phases were covered: 1- selection of the hypothesis or question of research; 2 - search strategy (establishment of inclusion and exclusion criteria, database and selection of studies); 3 - categorization of studies (extraction, organization and summarization of data); 4- evaluation of studies included in the review; 5 - interpretation of results and 6- synthesis of knowledge ${ }^{(15)}$.

To guide the study, the research question was elaborated following the PICO strategy (Participant, Intervention, Comparison and Outcomes) (17): "Is the implementation of the multimodal strategy effective in health professionals compliance with Hand Hygiene and can it be sustained over time?".

Inclusion criteria were original scientific articles using a quantitative approach that used an intervention to improve HH compliance, using a standardized and validated WHO observation form to calculate $\mathrm{HH}$ compliance index, which considers the opportunity for $\mathrm{HH}$ and the action performed. It should be noted that articles published in English, Spanish or Portuguese were included in the period from 2009 to 2017. This period of time is justified by the year of dissemination of said strategy by WHO, which was in 2009.

Publications such as theses and dissertations, studies in which the method was not clearly and adequately described, carried out only with students and did not include at least two key components of the WHO multimodal strategy or were not available in full were excluded from the review. Data collection occurred between May and October 2017.

The primary studies were searched in the following databases: Medical Literature Analysis and Retrieval System Online (MEDLINE), Latin American and Caribbean Literature in Health Sciences (LILACS), Current Nursing and Allied Health Literature (CINAHL) and SCOPUS. In order to ensure a careful search, the controlled descriptors (Health Science Descriptors (DeCS), Medical Subject Headings (MeSH) and CINAHL Headings were defined, and not controlled (keywords). The DeCS used were: higiene das mãos and pessoal de saúde, MeSH: hand hygiene and health personnel, and CINAHL Headings: handwashing and health personnel, and the keywords: adesão/compliance, intervenção/intervention, programa de avaliação/program evaluation aand estratégia multimodal/multimodal strategy. The use of the Boolean operator (AND) allowed access to articles with intersections between descriptors and keywords, and the terms were combined in different ways, according to each database, to ensure wide and adequate search. Chart 1 shows the search mechanism used in each database and the number of articles retrieved. 
Chart 1 - Search engine and number of texts retrieved in different databases, 2017.

\begin{tabular}{|c|c|c|}
\hline $\begin{array}{l}\text { Databases } \\
\text { (Total) }\end{array}$ & Crossover - Descriptors & $\begin{array}{c}\text { Articles } \\
\text { obtained }\end{array}$ \\
\hline \multirow{5}{*}{$\begin{array}{l}\text { MEDLINE } \\
\text { (11) }\end{array}$} & hand hygiene AND health personnel & 9 \\
\hline & hand hygiene AND compliance & - \\
\hline & hand hygiene AND intervention & - \\
\hline & hand hygiene AND program evaluation & - \\
\hline & hand hygiene AND multimodal strategies & 2 \\
\hline \multirow{5}{*}{$\begin{array}{c}\text { SCOPUS } \\
(12)\end{array}$} & hand hygiene AND health personnel & 11 \\
\hline & hand hygiene AND compliance & - \\
\hline & hand hygiene AND intervention & - \\
\hline & hand hygiene AND program evaluation & - \\
\hline & hand hygiene AND multimodal strategies & 1 \\
\hline \multirow{5}{*}{$\begin{array}{l}\text { LILACS } \\
(02)\end{array}$} & higiene das mãos AND pessoal de saúde & 2 \\
\hline & higiene das mãos AND adesão & - \\
\hline & higiene das mãos AND intervenção & - \\
\hline & higiene das mãos AND programa de avaliação & - \\
\hline & higiene das mãos AND estratégia multimodal & - \\
\hline \multirow{5}{*}{$\begin{array}{c}\text { CINAHL } \\
(00)\end{array}$} & handwashing AND health personnel & - \\
\hline & handwashing AND compliance & - \\
\hline & handwashing AND intervention & - \\
\hline & handwashing AND program evaluation & - \\
\hline & handwashing AND multimodal strategies & - \\
\hline Total & & 25 \\
\hline
\end{tabular}

9,109 publications were found and 25 articles were eligible in order to compose the sample of the present study (Figure 1).

It should be noted that, in total, 166 articles selected for complete reading were excluded, of which 88 were excluded because they did not include at least two of the components of the multimodal strategy; 35 articles because they were not studies with the pre-established design; 15 articles because they did not present the adhesion index to pre and/or post-intervention $\mathrm{HH} ; 14$ articles because they are unavailable in full even after searching for switching service; 6 articles for being carried out in Primary Care; 5 because they were carried out only with students from the Health area and 3 because they were from another language, other than English, Portuguese or Spanish.

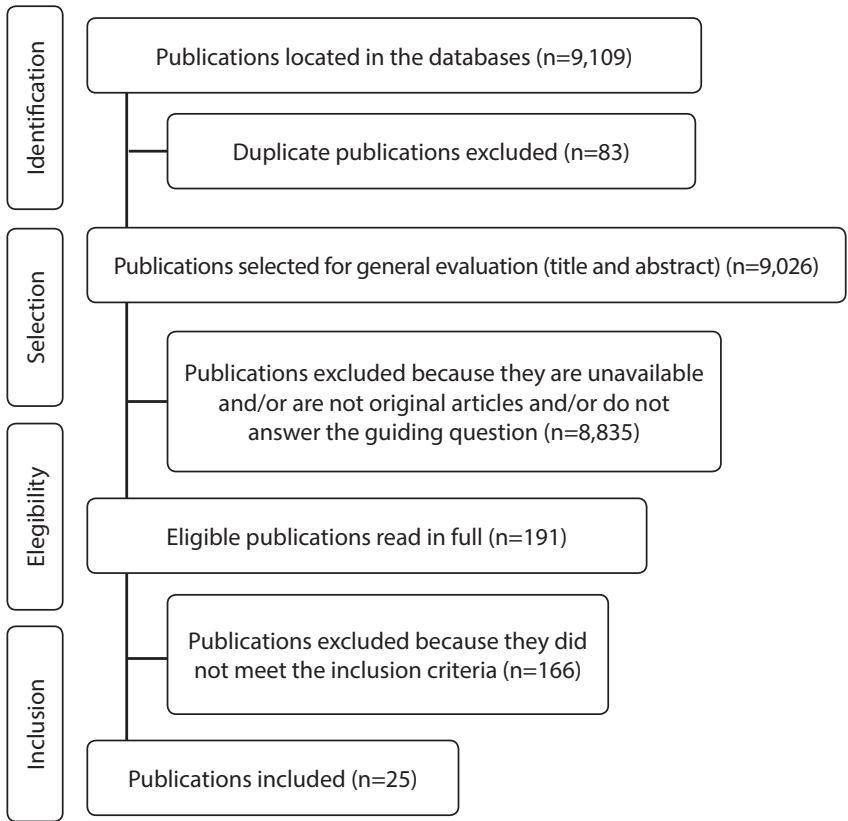

Figure 1 - Flowchart for identifying and selecting publications according to the PRISMA Statement

In the selection of articles, a careful reading of the title and the abstract was carried out, in order to verify the adequacy with the guiding question and, later, a complete reading of the manuscripts for certification of the inclusion and exclusion criteria established, being analysis of the articles performed in a descriptive way.

25 reviews were carried out that were strictly linked to the research object. The selection and analysis of the studies were conducted by two researchers, independently, in order to avoid biases in the screening of articles and in the inferences of the results.

\section{RESULTS}

Based on the inclusion criteria, the final sample consisted of 25 articles. The main information extracted from the original article for this study is presented in Chart 2.

The study participants were composed of nursing staff, physicians and other health professionals, who predominantly worked in the adult Intensive Care Unit (ICU), medical clinic, emergency departments, pediatric clinic and surgical clinic.

Chart 2 - Synopsis of key information from the 25 primary studies included in the integrative review, Brazil, 2018

\begin{tabular}{|c|c|c|c|c|c|c|c|}
\hline $\begin{array}{l}\text { Author, } \\
\text { Year and } \\
\text { Country }\end{array}$ & Outlining & $\begin{array}{c}\text { Components } \\
\text { of the } \\
\text { multimodal } \\
\text { strategy }\end{array}$ & Main actions developed & $\begin{array}{c}\text { Post- } \\
\text { intervention } \\
\text { index and } \\
\text { opportunities } \\
\text { (n) }\end{array}$ & $\begin{array}{l}\text { Post- } \\
\text { intervention } \\
\text { evaluation } \\
\text { time }\end{array}$ & $\begin{array}{c}\text { Post- } \\
\text { intervention } \\
\text { index and } \\
\text { opportunities } \\
\text { (n) }\end{array}$ & $P$ value \\
\hline $\begin{array}{l}\text { Mathai, A. S. et } \\
\text { al. }^{(18)} \\
2011 \\
\text { India }\end{array}$ & $\begin{array}{l}\text { Quasi- } \\
\text { experimental }\end{array}$ & $\begin{array}{l}\text { 1. System } \\
\text { change. } \\
\text { 2. Education/ } \\
\text { Training. } \\
\text { 4. Reminders } \\
\text { in the } \\
\text { workplace. }\end{array}$ & $\begin{array}{l}\text { 1. Alcohol gel-based solutions } \\
\text { and dispensers increase. } \\
\text { 2. Four lectures with slides over } \\
5 \mathrm{M} \text { for HH lasting } 1 \text { hour each, } \\
\text { for } 8 \text { weeks. } \\
\text { 4. Posters in the corridors and } \\
\text { next to each patient. }\end{array}$ & $\begin{array}{l}25.95 \% \\
n=1,001\end{array}$ & $\begin{array}{l}\text { Immediately } \\
\text { after } \\
\text { intervention }\end{array}$ & $\begin{array}{c}57.36 \% \\
n=1,026\end{array}$ & $<0.001$ \\
\hline
\end{tabular}




\begin{tabular}{|c|c|c|c|c|c|c|c|}
\hline $\begin{array}{l}\text { Author, } \\
\text { Year and } \\
\text { Country }\end{array}$ & Outlining & $\begin{array}{l}\text { Components } \\
\text { of the } \\
\text { multimodal } \\
\text { strategy }\end{array}$ & Main actions developed & $\begin{array}{c}\text { Post- } \\
\text { intervention } \\
\text { index and } \\
\text { opportunities } \\
\text { (n) }\end{array}$ & $\begin{array}{l}\text { Post- } \\
\text { intervention } \\
\text { evaluation } \\
\text { time }\end{array}$ & $\begin{array}{c}\text { Post- } \\
\text { intervention } \\
\text { index and } \\
\text { opportunities } \\
\text { (n) }\end{array}$ & $P$ value \\
\hline $\begin{array}{l}\text { Borges. L. F. A. } \\
\text { et al. }{ }^{(19)} \\
2012 \\
\text { Brazil }\end{array}$ & $\begin{array}{l}\text { Quasi- } \\
\text { experimental }\end{array}$ & $\begin{array}{l}\text { 1. System } \\
\text { change. } \\
\text { 3. Evaluation } \\
\text { and Feedback. } \\
\text { 4. Reminders } \\
\text { in the } \\
\text { workplace. }\end{array}$ & $\begin{array}{l}\text { 1. Alcohol gel-based solutions. } \\
\text { 3. Meetings to provide feedback } \\
\text { to } \mathrm{HH} \text { and } \mathrm{HCAl} \text { rate, twice per } \\
\text { industry. } \\
\text { 4. Colorful posters about } \mathrm{HH} \\
\text { importance. }\end{array}$ & $\begin{array}{c}21 \% \\
n=119\end{array}$ & $\begin{array}{l}\text { Immediately } \\
\text { after } \\
\text { intervention }\end{array}$ & $\begin{array}{l}24.80 \% \\
n=117\end{array}$ & 0.68 \\
\hline $\begin{array}{l}\text { Mestre, G. et } \\
\text { al. }^{(20)} \\
2012 \\
\text { Spain }\end{array}$ & $\begin{array}{l}\text { Quasi- } \\
\text { experimental }\end{array}$ & $\begin{array}{l}\text { 1. System } \\
\text { change. } \\
\text { 2. Education/ } \\
\text { Training. } \\
\text { 3. Evaluation } \\
\text { and Feedback. } \\
\text { 4. Reminders } \\
\text { in the } \\
\text { workplace. } \\
\text { 5. Institutional } \\
\text { Security } \\
\text { Environment. }\end{array}$ & $\begin{array}{l}\text { 1. Alcohol gel-based solutions. } \\
\text { 2. Theoretical-practical workshops } \\
\text { to encourage compliance and } \\
\text { correct HH technique. } \\
\text { 3. Creation of an HH monitoring } \\
\text { team, workplace evaluators, with } \\
\text { bimonthly feedback and control } \\
\text { of alcohol use in gel. } \\
\text { 4. Posters at the most popular } \\
\text { places. } \\
\text { 5. Management commitment and } \\
\text { nursing direction. }\end{array}$ & $\begin{array}{l}57 \% \\
n=N A\end{array}$ & $\begin{array}{l}\text { Immediately } \\
\text { after } \\
\text { intervention } \\
\text { and after } 1 \\
\text { year }\end{array}$ & $\begin{array}{c}\text { 2010: } 78 \% \\
n=4,095 \\
\\
2011: \\
84 \% \\
n=761\end{array}$ & $<0.001$ \\
\hline $\begin{array}{l}\text { Mazi, W. et al. }{ }^{(21)} \\
2013 \\
\text { Saudi Arabia }\end{array}$ & $\begin{array}{l}\text { Quasi- } \\
\text { experimental }\end{array}$ & $\begin{array}{l}\text { 1. System } \\
\text { change. } \\
\text { 2. Education/ } \\
\text { Training. } \\
\text { 3. Evaluation } \\
\text { and Feedback. } \\
\text { 5. Institutional } \\
\text { Security } \\
\text { Environment. }\end{array}$ & $\begin{array}{l}\text { 1. Alcohol gel-based solutions } \\
\text { and chlorhexidine. } \\
\text { 2. Practical lectures and } \\
\text { workshops on the } 5 \mathrm{M} \text { of } \mathrm{HH} \text {, } \\
\text { active methodology and } \\
\text { products for } \mathrm{HH} \text {, for } 3 \text { weeks. } \\
\text { 3. Quarterly reports were sent } \\
\text { to the team leaders and the } \\
\text { hospital director. } \\
\text { 5. Involvement of management } \\
\text { and team leaders to implement } \\
\text { strategies. }\end{array}$ & 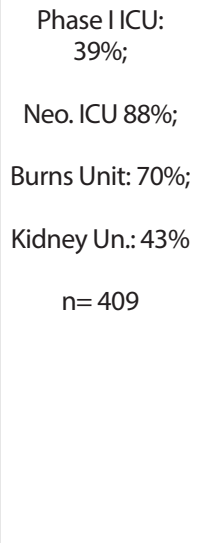 & $\begin{array}{l}\text { Phase II April/ } \\
\text { May } 2010 \\
\text { Phase III } \\
\text { October } 2010 \\
\text { Phase IV } \\
\text { March } 2011\end{array}$ & $\begin{array}{c}\text { Phase II } \\
\text { ICU at: 57\%; Neo. } \\
\text { ICU: 90\%; Burns: } \\
\text { 85\%; Kidney: 71\% } \\
\text { n=406 } \\
\text { Phase III } \\
\text { ICU at: 53\%; Neo. } \\
\text { ICU 90\%; Burns: } \\
\text { 78\%; Kidney: 36\% } \\
\text { n=620 } \\
\text { Phase IV } \\
\text { ICU at: } 81 \% ; \text { Neo. } \\
\text { ICU: 68\%; Burns: } \\
\text { 53\%; Kidney: 54\% } \\
\text { n=540 }\end{array}$ & $\begin{array}{c}\text { Adult ICU <0.05 } \\
\text { Neonatal ICU } \\
\text { and Burns Unit } \\
\text { dropped over } \\
\text { the course of } \\
15 \text { months. }\end{array}$ \\
\hline $\begin{array}{l}\text { Schmitz, K. et } \\
\text { al.(22) } \\
2014 \\
\text { Ethiopia }\end{array}$ & $\begin{array}{l}\text { Quasi- } \\
\text { experimental }\end{array}$ & $\begin{array}{l}\text { 1. System } \\
\text { change. } \\
\text { 2. Education/ } \\
\text { Training. } \\
\text { 3. Evaluation } \\
\text { and Feedback. } \\
\text { 4. Reminders } \\
\text { in the } \\
\text { workplace. }\end{array}$ & $\begin{array}{l}\text { 1. Non-water-soluble soap } \\
\text { and antiseptics, individually } \\
\text { distributed. } \\
\text { 2. Training on the importance } \\
\text { of HH with "Hand Hygiene } \\
\text { Champions" methodology for } 6 \\
\text { weeks. } \\
\text { 3. Monitoring and weekly } \\
\text { feedback to workers. } \\
\text { 4. HH posters throughout the } \\
\text { hospital. }\end{array}$ & $\begin{array}{c}2.10 \% \\
n= \\
1,000\end{array}$ & $\begin{array}{l}\text { Immediately } \\
\text { after } \\
\text { intervention }\end{array}$ & $\begin{array}{l}12.70 \% \\
n=1,000\end{array}$ & $<0.001$ \\
\hline $\begin{array}{l}\text { Restrepo, A.V. } \\
\text { et al. }{ }^{(23)} \\
2014 \text { Colombia }\end{array}$ & $\begin{array}{l}\text { Quasi- } \\
\text { experimental }\end{array}$ & $\begin{array}{l}\text { 1. System } \\
\text { change. } \\
\text { 2. Education/ } \\
\text { Training. } \\
\text { 3. Evaluation } \\
\text { and Feedback. } \\
\text { 4. Reminders } \\
\text { in the } \\
\text { workplace. } \\
\text { 5. Institutional } \\
\text { Security } \\
\text { Environment. }\end{array}$ & $\begin{array}{l}\text { 1. Alcohol gel-based solutions. } \\
\text { 2. Training on the } 5 \mathrm{M} \text { to } \mathrm{HH} \text {. } \\
\text { Meetings on the importance of } \\
\mathrm{HH} \text { by using audiovisual aids and } \\
\text { handing out } \mathrm{HH} \text { brochures. } \\
\text { 3. Immediate feedback to workers } \\
\text { after observation. } \\
\text { 4. } 5 \mathrm{M} \text { posters for } \mathrm{HH} \text { in all rooms, } \\
\text { and correct } \mathrm{HH} \text { technique above } \\
\text { dispensers and washbasins. } \\
\text { 5. Continuous action plan with } \\
\text { coordinators and directors to follow } \\
\text { up the strategy. }\end{array}$ & $\begin{array}{c}82 \% \\
n=1,279\end{array}$ & $\begin{array}{l}\text { Immediately } \\
\text { after } \\
\text { intervention }\end{array}$ & $\begin{array}{c}89 \% \\
n=1,962\end{array}$ & 0.007 \\
\hline
\end{tabular}




\begin{tabular}{|c|c|c|c|c|c|c|c|}
\hline $\begin{array}{l}\text { Author, } \\
\text { Year and } \\
\text { Country }\end{array}$ & Outlining & $\begin{array}{l}\text { Components } \\
\text { of the } \\
\text { multimodal } \\
\text { strategy }\end{array}$ & Main actions developed & $\begin{array}{c}\text { Post- } \\
\text { intervention } \\
\text { index and } \\
\text { opportunities } \\
\text { (n) }\end{array}$ & $\begin{array}{c}\text { Post- } \\
\text { intervention } \\
\text { evaluation } \\
\text { time }\end{array}$ & $\begin{array}{c}\text { Post- } \\
\text { intervention } \\
\text { index and } \\
\text { opportunities } \\
\text { (n) }\end{array}$ & $P$ value \\
\hline $\begin{array}{l}\text { Mahfouz, A. A. } \\
\text { et al. }{ }^{(24)} \\
2014 \\
\text { Saudi Arabia }\end{array}$ & $\begin{array}{l}\text { Quasi- } \\
\text { experimental }\end{array}$ & $\begin{array}{l}\text { 1. System } \\
\text { change. } \\
\text { 2. Education/ } \\
\text { Training. } \\
\text { 3. Evaluation } \\
\text { and Feedback. } \\
\text { 4. Reminders } \\
\text { in the } \\
\text { workplace. } \\
\text { 5. Institutional } \\
\text { Security } \\
\text { Environment. }\end{array}$ & $\begin{array}{l}\text { 1. Alcohol gel-based solutions at } \\
\text { the entrance of the rooms and } \\
\text { above each bed. } \\
\text { 2. Continuous meetings on } \\
\text { patient safety, HCAl, } 5 \mathrm{M} \text { for } \mathrm{HH} \\
\text { and correct HH techniques, } \\
\text { through videos and slides. Each } \\
\text { training session lasted } 2 \text { to } 3 \\
\text { hours. } \\
\text { 3. Evaluation and Feedback } \\
\text { passed on monthly to } \\
\text { management and employees. } \\
4 . \text { Distribution of posters by the } \\
\text { hospital. } \\
5 . \text { Involvement of leaders in } \\
\text { training offered. }\end{array}$ & $\begin{array}{l}57,90 \% \\
n=1,182\end{array}$ & After 1 year & $\begin{array}{l}84.90 \% \\
n=2,212\end{array}$ & 0.001 \\
\hline $\begin{array}{l}\text { Leblebicioglu, } \\
\text { H. et al. }{ }^{(13)} \\
2015 \\
\text { Turkey }\end{array}$ & $\begin{array}{l}\text { Quasi- } \\
\text { experimental }\end{array}$ & $\begin{array}{l}\text { 1. System } \\
\text { change. } \\
\text { 2. Education/ } \\
\text { Training. } \\
\text { 3. Evaluation } \\
\text { and Feedback. } \\
\text { 4. Reminders } \\
\text { in the } \\
\text { workplace. } \\
\text { 5. Institutional } \\
\text { Security } \\
\text { Environment. }\end{array}$ & $\begin{array}{l}\text { 1. Alcohol gel-based solutions } \\
\text { at the ICU entrances and at the } \\
\text { nursing posts. The sinks were } \\
\text { stocked with water, antiseptic } \\
\text { soap and paper towels } \\
\text { continuously. } \\
\text { 2. 30-minute education sessions } \\
\text { were held in each shift, with } \\
\text { monthly duration, every two } \\
\text { months and every six months, } \\
\text { depending on the sector. } \\
\text { 3. Monthly report sent to ICU } \\
\text { with HH membership rate. } \\
\text { 4. HH posters and reminders at } \\
\text { various hospital sites. } \\
\text { 5. Hospital administrators } \\
\text { agreed and committed to the } \\
\text { study. }\end{array}$ & $\begin{array}{c}29 \% \\
n=2,825\end{array}$ & $\begin{array}{l}\text { Immediately } \\
\text { after } \\
\text { intervention } \\
\text { and up to } 6 \\
\text { years later }\end{array}$ & $\begin{array}{c}45.50 \% \\
3 \text { months after: } \\
43.40 \% \\
2^{\text {nd }} \text { year: } 45.50 \% \\
3^{\text {rd }} \text { year: } 48.70 \% \\
4^{\text {th }} \text { year: } 73.30 \% \\
6^{\text {th }} \text { year: } 91 \% \\
n= \\
19,320 \text { (in the } \\
\text { course of } 6 \\
\text { years) }\end{array}$ & $<0.0001$ \\
\hline $\begin{array}{l}\text { Chen, J. K. et } \\
\text { al. } \\
\text { 2016 Taiwan }\end{array}$ & $\begin{array}{l}\text { Quasi- } \\
\text { experimental }\end{array}$ & $\begin{array}{l}\text { 1. System } \\
\text { change. } \\
\text { 2. Education/ } \\
\text { Training. } \\
\text { 3. Evaluation } \\
\text { and Feedback. } \\
\text { 4. Reminders } \\
\text { in the } \\
\text { workplace. } \\
\text { 5. Institutional } \\
\text { Security } \\
\text { Environment. }\end{array}$ & $\begin{array}{l}\text { 1. Change in the infrastructure } \\
\text { and supply of alcohol gel. } \\
\text { 2. Training of directors and } \\
\text { department leaders to offer } \\
\text { lectures, workshops and } \\
\text { videos on the importance of } \\
\text { membership and the impact of } \\
\mathrm{HH} \text { in the reduction of HCAI for } \\
3 \text { months. } \\
\text { 3. Monthly feedback on } \mathrm{HH} \text { and } \\
\text { later annual membership. } \\
\text { 4. Posters about the } 5 \mathrm{M} \text { for } \mathrm{HH} \\
\text { at the infirmary entrances. } \\
\text { 5. Director of the hospital } \\
\text { supported the intervention and } \\
\text { stressed the importance of hand } \\
\text { hygiene. }\end{array}$ & $\begin{array}{l}56.70 \% \\
n=1,760\end{array}$ & $\begin{array}{l}\text { Immediately } \\
\text { after } \\
\text { intervention } \\
\text { and after } 4 \\
\text { years }\end{array}$ & $\begin{array}{c}2010 \\
69.44 \% \\
n=5.472 \\
2015 \\
83,40 \% \\
n=N A\end{array}$ & $<0.05$ \\
\hline $\begin{array}{l}\text { Sakihama, T. et } \\
\text { al.(26) } \\
2016 \\
\text { Japan }\end{array}$ & $\begin{array}{l}\text { Quasi- } \\
\text { experimental }\end{array}$ & $\begin{array}{l}\text { 1. System } \\
\text { change. } \\
\text { 2. Education/ } \\
\text { Training. } \\
\text { 3. Evaluation } \\
\text { and Feedback. } \\
\text { 4. Reminders } \\
\text { in the } \\
\text { workplace. } \\
\text { 5. Institutional } \\
\text { Security } \\
\text { Environment. }\end{array}$ & $\begin{array}{l}\text { 1. Alcohol gel-based solutions at } \\
\text { the entrance of the wards. } \\
\text { 2. Regular seminars and lectures } \\
\text { on HH. } \\
\text { 3. Feedback from HH rate to CCIH } \\
\text { (Comissões de Controle de Infecção } \\
\text { Hospitalar - Hospital Infection } \\
\text { Control Commissions) and } \\
\text { participating clinics. } \\
\text { 4. Posters for all participating } \\
\text { clinics. } \\
\text { 5. Only Hospital A had a } \\
\text { management commitment. }\end{array}$ & $\begin{array}{c}\text { General Index: } \\
18 \% \\
\text { Hosp A: } 11.50 \% \\
\text { Hosp B: } 24.70 \% \\
\text { Hosp C: } 18.90 \% \\
n=2,679\end{array}$ & $\begin{array}{l}\text { Hospital A } \\
\text { and B after } \\
2 \text { months } \\
\text { and hospital } \\
\text { C after } 3 \\
\text { months of } \\
\text { intervention }\end{array}$ & $\begin{array}{c}\text { General Index: } \\
32,70 \% \\
\text { Hosp A: } 39,90 \% \\
\text { Hosp B: } 30 \% \\
\text { Hosp C: } 26.50 \% \\
n=2,982\end{array}$ & $\begin{array}{c}\text { General Index } \\
<\mathbf{0 . 0 0 1} \\
\text { Hospital A } \\
\text { had a higher } \\
\text { compliance rate } \\
(+29 \%) .\end{array}$ \\
\hline
\end{tabular}




\begin{tabular}{|c|c|c|c|c|c|c|c|}
\hline $\begin{array}{l}\text { Author, } \\
\text { Year and } \\
\text { Country }\end{array}$ & Outlining & $\begin{array}{l}\text { Components } \\
\text { of the } \\
\text { multimodal } \\
\text { strategy }\end{array}$ & Main actions developed & $\begin{array}{l}\text { Post- } \\
\text { intervention } \\
\text { index and } \\
\text { opportunities } \\
\text { (n) }\end{array}$ & $\begin{array}{l}\text { Post- } \\
\text { intervention } \\
\text { evaluation } \\
\text { time }\end{array}$ & $\begin{array}{c}\text { Post- } \\
\text { intervention } \\
\text { index and } \\
\text { opportunities } \\
\text { (n) }\end{array}$ & $P$ value \\
\hline $\begin{array}{l}\text { Patel, B. et al. }{ }^{(27)} \\
2016 \\
\text { South Africa }\end{array}$ & $\begin{array}{l}\text { Quasi- } \\
\text { experimental }\end{array}$ & $\begin{array}{l}\text { 1. System } \\
\text { change. } \\
\text { 2. Education/ } \\
\text { Training. } \\
\text { 3. Evaluation } \\
\text { and Feedback. } \\
\text { 4. Reminders } \\
\text { in the } \\
\text { workplace. } \\
\text { 5. Institutional } \\
\text { Security } \\
\text { Environment. }\end{array}$ & $\begin{array}{l}\text { 1. Alcohol gel-based solutions } \\
\text { and paper towel. } \\
\text { 2. Trained professionals } \\
\text { conducted HH's } 5 \mathrm{M} \text { educational } \\
\text { presentation to the team at } \\
\text { least once a week for } 3 \text { months. } \\
\text { 3. Monthly feedback and } \\
\text { performance charts for use in } \\
\text { group educational sessions. } \\
4.5 \mathrm{M} \text { posters for HH above the } \\
\text { sinks. } \\
5 . \text { Creating a continuous culture } \\
\text { of improvement and behavior } \\
\text { change. }\end{array}$ & $\begin{array}{c}\text { Before contact } \\
\text { with patient: } \\
\quad 34 \% \\
\text { After contact } \\
\text { with patient: } \\
\quad 47 \% \\
\text { n= NA }\end{array}$ & After 1 year & $\begin{array}{c}\text { Before contact } \\
\text { with patient: } \\
76 \% \\
\text { After contact } \\
\text { with patient: } \\
82 \% \\
\text { n= NA }\end{array}$ & $<0.05$ \\
\hline $\begin{array}{l}\text { Trannin, K. P.P. } \\
\text { et al.(28) } \\
2016 \\
\text { Brazil }\end{array}$ & $\begin{array}{l}\text { Quasi- } \\
\text { experimental }\end{array}$ & $\begin{array}{l}\text { 1. System } \\
\text { change. } \\
\text { 2. Education/ } \\
\text { Training. } \\
\text { 3. Evaluation } \\
\text { and Feedback. } \\
\text { 4. Reminders in } \\
\text { the workplace. }\end{array}$ & $\begin{array}{l}\text { 1. Individual alcohol gel-based } \\
\text { solutions. } \\
\text { 2. Film about the importance of } \\
\text { HH for } 1 \text { week. } \\
\text { 3. Presentation of data collected } \\
\text { on HH rates. } \\
\text { 4. Sectors posters and colorful } \\
\text { brooches as a reminder. }\end{array}$ & $\begin{array}{l}28.60 \% \\
n=2,304\end{array}$ & After 1 month & $\begin{array}{l}38.90 \% \\
n=2,757\end{array}$ & $<0.0001$ \\
\hline $\begin{array}{l}\text { Mu, X. et al. }{ }^{(29)} \\
2016 \\
\text { China }\end{array}$ & $\begin{array}{l}\text { Quasi- } \\
\text { experimental }\end{array}$ & $\begin{array}{l}\text { 1. System } \\
\text { change. } \\
\text { 2. Education/ } \\
\text { Training. } \\
\text { 3. Evaluation } \\
\text { and Feedback. } \\
\text { 4. Reminders } \\
\text { in the } \\
\text { workplace. }\end{array}$ & $\begin{array}{l}\text { 1. Exchange of conventional } \\
\text { faucets for faucets with sensors, } \\
\text { alcohol-based gel solutions and } \\
\text { paper towels. } \\
\text { 2. Two HH education } \\
\text { conferences and video } \\
\text { presentations on appropriate } \\
\text { HH techniques. } \\
\text { 3. Every quarter, a final report } \\
\text { on HH's membership in the } \\
\text { consumption of products was } \\
\text { sent to the hospital director and } \\
\text { heads of units for } 17 \text { months. } \\
\text { 4. Posters with correct HH } \\
\text { technique at all clinics, above } \\
\text { washbasins. }\end{array}$ & $\begin{array}{l}37.78 \% \\
n=1,266\end{array}$ & $\begin{array}{l}\text { Immediately } \\
\text { after } \\
\text { intervention }\end{array}$ & $\begin{array}{c}75.90 \% \\
n= \\
26,586 \text { (in the } \\
\text { course of } 17 \\
\text { months) }\end{array}$ & $<0.001$ \\
\hline $\begin{array}{l}\text { O'Donoghue, } \\
\text { et al. }{ }^{(30)} \\
2016 \\
\text { China }\end{array}$ & $\begin{array}{l}\text { Quasi- } \\
\text { experimental }\end{array}$ & $\begin{array}{l}\text { 1. System } \\
\text { change. } \\
\text { 2. Education/ } \\
\text { Training. } \\
\text { 4. Reminders } \\
\text { in the } \\
\text { workplace. }\end{array}$ & $\begin{array}{l}\text { 1. Alcohol gel-based solutions } \\
\text { next to each place where the } \\
\text { tests were performed. } \\
\text { 2. Training and updates of } \\
15 \text { minutes on the benefits } \\
\text { of } \mathrm{HH} \text { and correct use of } \\
\text { alcohol gel, performed three } \\
\text { times at the beginning of the } \\
\text { implementation and repeated } 1 \\
\text { month later. } \\
\text { 4. Pamphlets and posters as } \\
\text { reminders. }\end{array}$ & $\begin{array}{l}28.90 \% \\
n=214\end{array}$ & After 2 weeks & $\begin{array}{l}51.40 \% \\
n=243\end{array}$ & $<0.01$ \\
\hline
\end{tabular}

To be continued 


\begin{tabular}{|c|c|c|c|c|c|c|c|}
\hline $\begin{array}{l}\text { Author, } \\
\text { Year and } \\
\text { Country }\end{array}$ & Outlining & $\begin{array}{l}\text { Components } \\
\text { of the } \\
\text { multimodal } \\
\text { strategy }\end{array}$ & Main actions developed & $\begin{array}{l}\text { Post- } \\
\text { intervention } \\
\text { index and } \\
\text { opportunities } \\
\text { (n) }\end{array}$ & $\begin{array}{l}\text { Post- } \\
\text { intervention } \\
\text { evaluation } \\
\text { time }\end{array}$ & $\begin{array}{l}\text { Post- } \\
\text { intervention } \\
\text { index and } \\
\text { opportunities } \\
\text { (n) }\end{array}$ & $P$ value \\
\hline $\begin{array}{l}\text { Farhoudi, F. et } \\
\text { al. }^{(4)} \\
2016 \\
\text { Iran }\end{array}$ & $\begin{array}{l}\text { Quasi- } \\
\text { experimental }\end{array}$ & $\begin{array}{l}\text { 1. System } \\
\text { change. } \\
\text { 2. Education/ } \\
\text { Training. } \\
\text { 3. Evaluation } \\
\text { and Feedback. } \\
\text { 4. Reminders } \\
\text { in the } \\
\text { workplace. } \\
\text { 5. Institutional } \\
\text { Security } \\
\text { Environment. }\end{array}$ & $\begin{array}{l}\text { 1. Alcohol gel-based solutions next } \\
\text { to all bedding and paper towel } \\
\text { supply. } \\
\text { 2. 2-part training course. In the first } \\
\text { part use the Power Point slides for } \\
\text { a period of } 2 \text { hours, followed by } 2 \\
\text { hours to fill out observation forms. } \\
\text { In the second part, enrollment } \\
\text { in educational courses on HCAl } \\
\text { control and prevention, twice a } \\
\text { year. } \\
\text { 3. Observation feedback to } \\
\text { workers. } \\
\text { 4. Posters and billboards on } \\
\text { HCAl prevention and control. } \\
\text { Promotional messages and correct } \\
\text { techniques were displayed on the } \\
\text { charts and exchanged monthly. } \\
5 . \text { The project has become a } \\
\text { hospital priority. }\end{array}$ & $\begin{array}{l}29.80 \% \\
n=255\end{array}$ & After 1 year & $\begin{array}{c}71 \% \\
n=193\end{array}$ & $<0.001$ \\
\hline $\begin{array}{l}\text { Arntz, P. R. H. } \\
\text { et al. }{ }^{(5)} \\
2016 \text { Holland }\end{array}$ & $\begin{array}{l}\text { Quasi- } \\
\text { experimental }\end{array}$ & $\begin{array}{l}\text { 1. System } \\
\text { change. } \\
\text { 2. Education/ } \\
\text { Training. } \\
\text { 3. Evaluation } \\
\text { and Feedback. } \\
\text { 4. Reminders } \\
\text { in the } \\
\text { workplace. }\end{array}$ & $\begin{array}{l}\text { 1. Alcohol gel-based solutions. } \\
\text { 2. Education about } 5 \mathrm{M} \text { for } \mathrm{HH} \\
\text { and the relevance of } \mathrm{HCAl} \\
\text { prevention, with daily training, } \\
\text { for } 3 \text { weeks. } \\
\text { 3. Daily feedback during the } \\
\text { second and third intervention } \\
\text { period. } \\
\text { 4. Distribution of posters in } \\
\text { the infirmaries and screen rest } \\
\text { in computers illustrating the } \\
\text { importance of HH. }\end{array}$ & $\begin{array}{l}18.20 \% \\
n=407\end{array}$ & $\begin{array}{l}\text { During } 3 \\
\text { weeks }\end{array}$ & $\begin{array}{c}1^{\text {st }} \text { sem.: } 40.50 \% \\
2^{\text {nd }} \text { sem.: } 49.50 \% \\
3^{\text {rd }} \text { sem.: } 45.70 \% \\
n=600\end{array}$ & $<0.001$ \\
\hline $\begin{array}{l}\text { Moghnieh, R. } \\
\text { et al. }{ }^{(31)} \\
2017 \text { Lebanon }\end{array}$ & Experimental & $\begin{array}{l}\text { 1. System } \\
\text { change. } \\
\text { 2. Education/ } \\
\text { Training. } \\
\text { 3. Evaluation } \\
\text { and Feedback. }\end{array}$ & $\begin{array}{l}\text { 1. Alcohol gel-based solutions } \\
\text { above the beds of all } \\
\text { participating sectors. } \\
\text { 2. Lecture about } 5 \mathrm{M} \text { for } \mathrm{HH} \text { was } \\
\text { initially introduced for all three } \\
\text { groups. } \\
\text { 3. With the incentive group a } \\
\text { weekly audit was performed } \\
\text { with the payment of an extra } 1 \\
\text { hour for the best performance. } \\
\text { For the feedback group, } \\
\text { individual and group feedback } \\
\text { was reviewed weekly, recalling } \\
\text { the importance of HH for HCAl } \\
\text { prevention. }\end{array}$ & $\begin{array}{c}\text { Control group: } \\
16 \% \\
\text { Incentive group: } \\
21 \% \\
\\
\text { Feedback } \\
\text { group: } 23 \% \\
n=\text { NA }\end{array}$ & $\begin{array}{l}\text { During } 21 \\
\text { weeks }\end{array}$ & $\begin{array}{l}\text { Control group: } \\
\text { 20\%; Incentive } \\
\text { group: } \\
8 \text { s: } 60 \% ; 14 \\
\text { s: } 77 \% ; 21 \mathrm{~s}: \\
\text { 34\%; Feedback } \\
\text { group: } \\
8 \mathrm{s:} 43 \% ; 14 \mathrm{~s}: \\
51 \% ; 21 \mathrm{~s}: 48 \% \\
\mathrm{n}=\mathrm{NA}\end{array}$ & $\begin{array}{l}\text { Control group } \\
\text { irrelevant. } \\
\text { Incentive and } \\
\text { feedback group } \\
<0.001 \text {. After } \\
\text { discontinuation } \\
\text { of interventions, } \\
\text { the incentive } \\
\text { group fell to } \\
34 \% \text { and the } \\
\text { feedback group } \\
\text { reached } 48 \% \\
(<0.0001) \text {. }\end{array}$ \\
\hline $\begin{array}{l}\text { Pfäfflin, F. et } \\
\text { al. }{ }^{(32)} \\
2017 \text { Ethiopia }\end{array}$ & $\begin{array}{l}\text { Quasi- } \\
\text { experimental }\end{array}$ & $\begin{array}{l}\text { 1. System } \\
\text { change. } \\
\text { 2. Education/ } \\
\text { Training. } \\
\text { 3. Evaluation } \\
\text { and Feedback. } \\
\text { 4. Reminders } \\
\text { in the } \\
\text { workplace. }\end{array}$ & $\begin{array}{l}\text { 1. Alcohol gel-based solutions } \\
\text { on the walls and pocket flasks. } \\
\text { 2. Workshop and lectures on } \\
\text { cultural aspects and scientific } \\
\text { evidence of HH and HCAl in } \\
\text { neonatology, during four days. } \\
\text { 3. Feedback of initial results for } \\
\text { hospital management and for } \\
\text { participants. Offer premium to } \\
\text { the sector that achieved the } \\
\text { highest compliance. } \\
\text { 4. Posters emphasizing the } \\
\text { importance of HH in strategic } \\
\text { places of greater circulation. }\end{array}$ & $\begin{array}{c}1.40 \% \\
n=2,888\end{array}$ & After 6 weeks & $\begin{array}{l}11.70 \% \\
n=2,865\end{array}$ & $<0.001$ \\
\hline
\end{tabular}




\begin{tabular}{|c|c|c|c|c|c|c|c|}
\hline $\begin{array}{l}\text { Author, } \\
\text { Year and } \\
\text { Country }\end{array}$ & Outlining & $\begin{array}{l}\text { Components } \\
\text { of the } \\
\text { multimodal } \\
\text { strategy }\end{array}$ & Main actions developed & $\begin{array}{c}\text { Post- } \\
\text { intervention } \\
\text { index and } \\
\text { opportunities } \\
\text { (n) }\end{array}$ & $\begin{array}{l}\text { Post- } \\
\text { intervention } \\
\text { evaluation } \\
\text { time }\end{array}$ & $\begin{array}{c}\text { Post- } \\
\text { intervention } \\
\text { index and } \\
\text { opportunities } \\
\text { (n) }\end{array}$ & $P$ value \\
\hline $\begin{array}{l}\text { Fariñas-Alvarez, } \\
\text { C. et al. }{ }^{(7)} \\
2017 \text { Spain }\end{array}$ & $\begin{array}{l}\text { Quasi- } \\
\text { experimental }\end{array}$ & $\begin{array}{l}\text { 1. System } \\
\text { change. } \\
\text { 2. Education/ } \\
\text { Training. } \\
\text { 3. Evaluation } \\
\text { and Feedback. } \\
\text { 4. Reminders } \\
\text { in the } \\
\text { workplace } \\
\text { 5. Institutional } \\
\text { Security } \\
\text { Environment. }\end{array}$ & $\begin{array}{l}\text { 1. Alcohol gel dispensers } \\
\text { with tracking date of product } \\
\text { placement. } \\
\text { 2. Face-to-face sessions } \\
\text { with 2-hour workshops with } \\
\text { theoretical and practical content } \\
\text { and online distance training. } \\
\text { 3. Individual feedback } \\
\text { reinforcing positive attitudes. } \\
\text { 4. Posters about the importance } \\
\text { of HH in the sectors. } \\
\text { 5. The improvement of HH was } \\
\text { considered a priority in hospital } \\
\text { safety and quality policies. }\end{array}$ & $\begin{array}{l}54.50 \% \\
n=N A\end{array}$ & $\begin{array}{l}\text { Immediately } \\
\text { after } \\
\text { intervention; } \\
\text { after } 2 \\
\text { months } \\
\text { and after } 6 \\
\text { months }\end{array}$ & $\begin{array}{l}\text { March: } 69.90 \% \\
\text { May: } 44.80 \% \\
\text { September: } \\
69.40 \% \\
\text { n= NA }\end{array}$ & $<0.001$ \\
\hline $\begin{array}{l}\text { Santosaningsih, } \\
\text { D. et al. }{ }^{(33)} \\
2017 \text { Indonesia }\end{array}$ & Experimental & $\begin{array}{l}\text { 1. System } \\
\text { change. } \\
\text { 2. Education/ } \\
\text { Training. } \\
\text { 4. Reminders } \\
\text { in the } \\
\text { workplace. }\end{array}$ & $\begin{array}{l}\text { 1. Alcohol gel-based solutions } \\
\text { next to each bed and door. } \\
\text { 2. There were three different } \\
\text { educational programs: active } \\
\text { presentations; paper template } \\
\text { training; and combination of } \\
\text { both, for } 8 \text { weeks. } \\
\text { 4. Posters presenting HH } \\
\text { procedures in workplaces. }\end{array}$ & $\begin{array}{c}\text { Pediatrics: } \\
\text { 24.10\% } \\
\text { Medical Clinic: } \\
5.20 \% \\
\text { Surgery: } 18.90 \% \\
\text { Without } \\
\text { intervention: } \\
\text { Ginec-obst: } \\
10.10 \% \\
\text { n= NA }\end{array}$ & $\begin{array}{l}\text { Immediately } \\
\text { after } \\
\text { intervention }\end{array}$ & $\begin{array}{c}\text { Pediatrics: } \\
\text { 43.70\% } \\
\text { Medical Clinic: } \\
18,50 \% \\
\text { Surgery: } 24,90 \% \\
\text { Without } \\
\text { intervention: } \\
\text { Ginec-obst: } \\
20,50 \% \\
\text { n= NA }\end{array}$ & $\begin{array}{l}\text { Medical Clinic } \\
\text { and surgery } \\
<0.01 \text { and } \\
\text { ginec-obst } \\
\text { and Pediatrics } \\
<\mathbf{0 . 0 0 1} \text {. }\end{array}$ \\
\hline $\begin{array}{l}\text { Visan, F. A. et } \\
\text { al. }^{(8)} \\
2017 \\
\text { Qatar }\end{array}$ & $\begin{array}{l}\text { Quasi- } \\
\text { experimental }\end{array}$ & $\begin{array}{l}\text { 1. System } \\
\text { change. } \\
\text { 2. Education/ } \\
\text { Training. } \\
\text { 3. Evaluation } \\
\text { and Feedback. } \\
\text { 4. Reminders } \\
\text { in the } \\
\text { workplace. } \\
\text { 5. Institutional } \\
\text { Security } \\
\text { Environment. }\end{array}$ & $\begin{array}{l}\text { 1. Installations of washbasin } \\
\text { and dispensers alcohol gel, } \\
\text { chlorhexidine and quaternary } \\
\text { ammonium compound in the } \\
\text { corridors and change of taps for } \\
\text { hand sensors. } \\
\text { 2. Behavior change model } \\
\text { conceptualized by Heath, } \\
\text { Change \& Heath to motivate HH } \\
\text { for } 25 \text { months. } \\
\text { 3. Monthly feedback to the } \\
\text { team. Certificates and positive } \\
\text { reinforcements for the first } \\
\text { three professionals who hand } \\
\text { sanitized. } \\
4 \text {. Available } 5 \mathrm{M} \text { HH posters on } \\
\text { top of washbasins. } \\
\text { 5. The hospital administration } \\
\text { supported and provided the } \\
\text { necessary subsidies. }\end{array}$ & $\begin{array}{c}\text { September to } \\
\text { December 2011: } \\
60.78 \% \\
n=N A\end{array}$ & $\begin{array}{l}\text { During } 4 \\
\text { years }\end{array}$ & $\begin{array}{l}\text { 2012: } 77.38 \% \\
\text { 2013: } 91.82 \% \\
\text { 2014: } 93.96 \% \\
2015: 95.54 \% \\
n=N A\end{array}$ & $\begin{array}{c}\text { Increased by } \\
\text { more than } 30 \% \\
\text { by the end } \\
\text { of December } \\
2015 .\end{array}$ \\
\hline $\begin{array}{l}\text { Pereira, E. B. S. } \\
\text { et al. } \\
2017 \\
\text { Brazil }\end{array}$ & $\begin{array}{l}\text { Quasi- } \\
\text { experimental }\end{array}$ & $\begin{array}{l}\text { 1. System } \\
\text { change. } \\
\text { 2. Education/ } \\
\text { Training. } \\
\text { 4. Reminders } \\
\text { in the } \\
\text { workplace. }\end{array}$ & $\begin{array}{l}\text { 1. Alcohol gel-based solutions. } \\
\text { 2. Video about the correct } \\
\text { technique for } \mathrm{HH} \text { and its } \\
\text { importance, for one week. } \\
\text { 4. Posters were placed in } \\
\text { strategic positions at the unit } \\
\text { and leaflets on } \mathrm{HH} \text { techniques } \\
\text { and } \mathrm{HH} \text { 5M. }\end{array}$ & $\begin{array}{c}\text { Nur.: } 48.70 \% \\
\text { Nursing assist.: } \\
53.62 \% \\
\text { Doctors: } 59.22 \% \\
\text { Physiotherapists: } \\
81.48 \% \\
n=1,070\end{array}$ & $\begin{array}{l}\text { After } 3 \\
\text { months }\end{array}$ & $\begin{array}{c}\text { Nurs.: } 54.91 \% \\
\text { Nursing assist. } \\
46.30 \% \\
\text { Doctors: } 67,46 \% \\
\text { Physiotherapists: } \\
\text { 79.59\% } \\
n=1,227\end{array}$ & 0.066 \\
\hline
\end{tabular}




\begin{tabular}{|c|c|c|c|c|c|c|c|}
\hline $\begin{array}{l}\text { Author, } \\
\text { Year and } \\
\text { Country }\end{array}$ & Outlining & $\begin{array}{l}\text { Components } \\
\text { of the } \\
\text { multimodal } \\
\text { strategy }\end{array}$ & Main actions developed & $\begin{array}{l}\text { Post- } \\
\text { intervention } \\
\text { index and } \\
\text { opportunities } \\
\text { (n) }\end{array}$ & $\begin{array}{l}\text { Post- } \\
\text { intervention } \\
\text { evaluation } \\
\text { time }\end{array}$ & $\begin{array}{c}\text { Post- } \\
\text { intervention } \\
\text { index and } \\
\text { opportunities } \\
\text { (n) }\end{array}$ & $P$ value \\
\hline $\begin{array}{l}\text { Shen, L. et al. }{ }^{(35)} \\
2017 \\
\text { China }\end{array}$ & $\begin{array}{l}\text { Quasi- } \\
\text { experimental }\end{array}$ & $\begin{array}{l}\text { 1. System } \\
\text { change. } \\
\text { 2. Education/ } \\
\text { Training. } \\
\text { 3. Evaluation } \\
\text { and Feedback. } \\
\text { 4. Reminders } \\
\text { in the } \\
\text { workplace. } \\
\text { 5. Institutional } \\
\text { Security } \\
\text { Environment. }\end{array}$ & $\begin{array}{l}\text { 1. Pocket alcohol gel-based } \\
\text { solutions, washbasins with paper } \\
\text { towels, automatic taps and liquid } \\
\text { soap dispensing sensor. } \\
\text { 2. HH } 5 \mathrm{M} \text { instruction video and its } \\
\text { correct technique and importance. } \\
\text { 3. Periodic feedback to } \\
\text { management, department heads, } \\
\text { industry nurses and some workers. } \\
\text { 4. Posters about correct HH } \\
\text { techniques near washbasins. } \\
\text { Colorful } 5 \mathrm{M} \text { posters in all nurses. } \\
\text { Computer screen reminders and } \\
\text { knowledge contest. } \\
5 . \text { CCIH department management } \\
\text { commitment to the study. quality } \\
\text { control through rewards and } \\
\text { punishments. }\end{array}$ & $\begin{array}{r}66.27 \% \\
n=1,675\end{array}$ & $\begin{array}{l}\text { Immediately } \\
\text { after } \\
\text { intervention }\end{array}$ & $\begin{array}{l}80.53 \% \\
n=3,369\end{array}$ & $<0.001$ \\
\hline $\begin{array}{l}\text { Kuwaití, A. A. }{ }^{(36)} \\
2017 \text { Saudi } \\
\text { Arabia }\end{array}$ & $\begin{array}{l}\text { Quasi- } \\
\text { experimental }\end{array}$ & $\begin{array}{l}\text { 1. System } \\
\text { change. } \\
\text { 2. Education/ } \\
\text { Training. } \\
\text { 3. Evaluation } \\
\text { and Feedback. } \\
\text { 4. Reminders } \\
\text { in the } \\
\text { workplace. } \\
\text { 5. Institutional } \\
\text { Security } \\
\text { Environment. }\end{array}$ & $\begin{array}{l}\text { 1. Alcohol gel-based solutions } \\
\text { and increased dispensers and } \\
\text { washbasins. } \\
\text { 2. Slide training on the } 5 \mathrm{M} \text { for } \\
\text { HH. Installation of screen saver } \\
\text { on computers to display the } 5 \mathrm{M} \\
\text { and education of companions, } \\
\text { for } 12 \text { months. } \\
\text { 3. Performance feedback to } \\
\text { professionals and regular audits. } \\
\text { 4. Posters above the washbasins. } \\
\text { 5. Holding meetings with the } \\
\text { hospital administration and the } \\
\text { team to obtain compliance. }\end{array}$ & $\begin{array}{l}50.17 \% \\
n=N A\end{array}$ & $\begin{array}{l}\text { During } 2 \\
\text { years }\end{array}$ & $\begin{array}{c}\text { 2015: } 66.08 \% \\
2016: \\
71.75 \% \\
n=N A\end{array}$ & $<0.05$ \\
\hline $\begin{array}{l}\text { Musu, M. et } \\
\text { al. }^{(37)} \\
2017 \\
\text { Italy }\end{array}$ & $\begin{array}{l}\text { Quasi- } \\
\text { experimental }\end{array}$ & $\begin{array}{l}\text { 2. Education/ } \\
\text { Training. } \\
\text { 3. Evaluation } \\
\text { and Feedback. } \\
\text { 4. Reminders } \\
\text { in the } \\
\text { workplace. }\end{array}$ & $\begin{array}{l}\text { 2. Brief review of the literature, } \\
\text { followed by practical } \\
\text { demonstrations, illustrative } \\
\text { videos and discussions about } \\
\text { HH, lasting } 7 \text { to } 10 \text { months. } \\
\text { 3. Performance feedback } \\
\text { through monthly meetings with } \\
\text { professionals. } \\
\text { 4. Posters and brochures affixed } \\
\text { to ICU and waiting room. }\end{array}$ & $\begin{array}{c}\text { Total: } 47 \% \\
\text { n= } 918\end{array}$ & $\begin{array}{l}\text { Immediately } \\
\text { after } \\
\text { intervention }\end{array}$ & $\begin{array}{c}\text { Total: } 89.40 \% \\
n=2,414\end{array}$ & $<0.001$ \\
\hline
\end{tabular}

Note: NA - Not Available; P value: demonstrates whether the intervention was statistically significant to improve HH compliance after the implementation of the multimodal strategy. $P$ - significant value $<$ or equal 0.05 .

It was observed that the five components of the multimodal strategy were not included in $52 \%$ of the studies. System change was in twenty-four studies (96\%); education/training in twentyfour (96\%); evaluation and feedback in twenty-one (84\%); workplace reminders in twenty-three (92\%) and institutional security environment in thirteen publications (52\%). It is noteworthy that only twelve studies used all the elements of this strategy, which represents, therefore, $48 \%$ of the studies included in the present sample.

With regard to the actions developed regarding the element change in the system, the availability of gel alcohol was present in the majority of studies that used this component, followed by increase of gel alcohol dispensers, paper towel, chlorhexidine, faucet with automatic sensor and washbasins. The most used educational and training strategies were lectures/courses addressing the theme of the five $\mathrm{HH}$ moments of the WHO, form of pathogen transmission and prevention and control of $\mathrm{HCAl}$ (23/25), followed by workshops (11/25). The preferred methodologies were theoretical presentations, using didactic resources such as slides, videos and films, practical demonstration and dialogue on the theme. The active methodology was cited in a study ${ }^{(21)}$, but did not present detailed information about its development.

The evaluation and feedback occurred through individually $(02 / 20)$ or collective $(11 / 20)$ meetings with the workers. In some studies weekly or monthly or quarterly reports were sent to department heads and/or hospital management (07/20). In all searches that had the reminder component in the workplace, educational posters were the preferred choice. Regarding research that explicitly made use of the institutional safety environment component, only three studies ${ }^{(7,23,27)}$ clearly stated that managers and managers committed to follow up on the implementation of the multimodal strategy after the study. 
Regarding the time of evaluation, this occurred immediately after the intervention (8/25), immediately and/or in a period equal to or less than six months $(8 / 25)$, for one year $(5 / 25)$, for two years $(1 / 25)$ for four years $(2 / 25)$ and for six years (1/25).

Among the results of the data analysis, only three articles (12\%) did not present statistically significant results ( $p$ value $<0.05$ ) to improve $\mathrm{HH}$ compliance after implementation of the multimodal strategy or showed a decrease in $\mathrm{HH}$ compliance over the evaluation time. The first of these studies carried out in Brazil ${ }^{(19)}$ used three of the five components of the multimodal strategy - change in the system, evaluation and feedback, and reminders in the workplace; the second was held in Saudi Arabia ${ }^{(21)}$, and in addition to the three previous components, also used education and training for three weeks. The third one was also developed in Brazil ${ }^{(34)}$ and included only three elements - change in the system, reminders in the workplace, and education and training for only one week.

\section{DISCUSSION}

The increase in research related to this topic in the last five years, especially between the years 2016 and 2017, whose publications corresponded to more than $60 \%(17 / 25)$ of the studies included. This growth in scientific studies may be related to several factors, such as the serious negative impact of HCAl worldwide, priority to research aimed at prevention and control of HCAl, which also include the Brazilian Agenda of Priorities in Health Research, as it represents the fifth international goal of patient safety, as well as the encouragement given by $\mathrm{WHO}$ and other international and national agencies to the use of the multimodal strategy to improve $\mathrm{HH}$ compliance ${ }^{(38-40)}$.

It is important to note that, although the study showed that the multimodal strategy, when correctly implemented, is capable of increasing workers' $\mathrm{HH}$ compliance, it is explicit that, in many cases, post-intervention compliance rates - even if statistically significant of $\mathrm{p}<0.05$ ) - are below what is necessary and expected $^{(5,7,18-19,21-22,26,28,30-33)}$.

According to the Global Human Development Index (HDI)(41), approximately $85 \%(21 / 25)$ of the countries in which the studies included in this review occurred have a very high or high $\mathrm{HDI}^{14-5,7-}$ $8,13,19-21,23-31,34-37)$. With respect to the medium and low HDI countries $(4 / 25)^{(18,22,32-33)}$, all had a pre-intervention $\mathrm{HH}$ compliance of less than $30 \%$, and a post-intervention compliance of less than $50 \%$, except a study ${ }^{(18)}(1 / 4)$ that reached $57 \%$ after the intervention. Some countries, such as Saudi Arabia ${ }^{(21,24,36)}$, Spain $^{(7,20)}$ and Qatar ${ }^{(8)}$, already had a higher pre-intervention rate than those with lower $\mathrm{HDI}$, such as Ethiopia(22,32), Indonesia ${ }^{(33)}$ and India ${ }^{(18)}$.

Also in this context, two studies carried out in Ethiopia(22,32), a country with a low $\mathrm{HDI}$, showed that pre-intervention $\mathrm{HH}$ compliance of $2.10 \%$ and $1.4 \%$ and even after educational implementation, post-intervention records remained at $12.70 \%$ and $11.70 \%$, respectively. Similarly, a study conducted in Indonesia ${ }^{(33)}$, an average HDI country, found that even after the implementation of a multimodal strategy, compliance rates in medical and surgical clinical practice remained at $18.5 \%$ and $24.9 \%$, respectively, and a study conducted in Brazil(19), although classified as a high $\mathrm{HDI}$ country, also deserves to be highlighted, with $24.8 \% \mathrm{HH}$ compliance even after applying these strategies.
A study ${ }^{(39)}$ that evaluated the implementation of the multimodal strategy in five countries with different classifications of economic development verified a more significant improvement in $\mathrm{HH}$ in low- and middle-income countries than in high-income countries, probably because in places where basic knowledge and physical resources are scarce, the contribution of the multimodal strategy can provide immediate and substantial progress, albeit far from what has been advocated. Even so, multicomponent intervention has proven viable and sustainable in all hospitals, including those with limited resources, and should be strongly encouraged.

It should also be noted that the study conducted in Brazil(19) did not achieve a significant compliance rate, possibly due to the fact that it did not use the element of the education/training program, a key element to change practices and behaviors, besides presenting limitations related to the number of registered opportunities (pre-intervention 119 and post-intervention 117), which hinders the understanding, interpretation and inference of the analyzed data.

A study in three hospitals in Japan ${ }^{(26)}$ showed that although $\mathrm{HH}$ compliance increased with the implementation of the five components of the multimodal strategy, the hospital that maintained the managers' commitment during and after the intervention was the one that most assured an increase in the rate of with approximately $30 \%$ increase, while the other two hospitals showed an increase of only $5 \%$ and $7 \%$, respectively.

It is in this overview that studies ${ }^{(8,21-22,28,30)}$ have shown that the institutional safety environment, education and training of health professionals, and feedback evaluation are three key components for increasing $\mathrm{HH}$ compliance and are capable of sustaining compliance rates for periods of time, since they consider Permanent Education and vicarious learning as a means to obtain constant improvements. Thus, in order to ensure a continuous change of improvement in $\mathrm{HH}$ and sustainability of compliance rates, a multimodal approach is essential, in a combined, periodic and permanent manner ${ }^{(3,39)}$, which did not occur in the mentioned studies ${ }^{(19,22,32-33)}$.

WHO itself recommends that in order to achieve a successful and sustained improvement in $\mathrm{HH}$, it is necessary to use several actions to address different institutional obstacles and behavioral barriers ${ }^{(2)}$. However, cultural changes do not occur quickly and spontaneously, they need to be permanent and always evaluated. The Brazilian Política Nacional de Educação Permanente em Saúde (PNEPS - freely translated as National Policy of Permanent Education in Health) considers health workers as the main agents of change, and the work environment is the ideal place to develop learning, enabling changes in professional practices ${ }^{(42)}$.

According to Bandura ${ }^{(43)}$, learning can be active or by observation, the latter being considered the main way to obtain knowledge, because it occurs by observing the behavior of other people and the experiences generated or obtained by them, called vicarious learning. In this sense, the importance of the social context for certain behaviors is evident, considering that encouragement for development comes from each subject, and that people reproduce behaviors or model themselves in some way according to others and the environment.

In this context, feedback from practices as a Permanent Education strategy can be considered a necessary and very useful element to increase and maintain $\mathrm{HH}$ improvement rates, since 
it allows identifying gaps and implementing actions directed at behavior change. When performed immediately and individually, it has influenced the performance of professionals by allowing the identification of barriers that interfere in the $\mathrm{HH}$ compliance and seek timely solutions, as well as to detect the types of opportunities and the reason for failures for $\mathrm{HH}$, highlighting the protagonism of the subject, that is, the central role of the health professional in the process of learning ${ }^{(20,30)}$. However, collective feedback is also an important alternative, since it is in the collective exercise of the process of knowledge construction that one can favor learning and enable the transformation of praxis ${ }^{(13,43-44)}$.

This review evidenced that the studies that sustained compliance over time were supported by the management and involvement of the institution's leaders, as well as a multidimensional approach, such as the study carried out in Saudi Arabia ${ }^{(24)}$, which increased HH compliance of $60.8 \%$ before the intervention to $84.9 \%$ after one year, involving the leaders during the training workshops and providing monthly feedback to the workers, ensuring their prominence.

In this sense, a study carried out in Turkey ${ }^{(13)}$ deserves special mention in maintaining the $91 \%$ rate of $\mathrm{HH}$ compliance after six years of the intervention period, with active participation of administrators during infection control meetings and education sessions with workers during all study follow-up. A similar survey, conducted in Taiwan ${ }^{(25)}$, maintained $\mathrm{HH}$ compliance in $83.4 \%$ after four years of intervention, with effective participation of management in the actions carried out and monthly feedback to health workers.

An experimental study in Lebanon ${ }^{(31)}$ verified that the group that received weekly feedback individually and collectively was the one that achieved the highest rate of $\mathrm{HH}$ compliance after intervention, with a statistically significant result $(p<0.001)$. It is worth noting the study by Visan et al. ${ }^{(8)}$, who during the meetings to feedback the practices, also provided certificates to the three best professionals of the adhesion, and together with the participation of management and active education, they sustained an index of $95.4 \%$ over four years.

It should be noted that the change in structure, represented mostly by the availability of alcohol gel and the supply of washbasins and paper towels, are no less important, since professionals need the means to perform $\mathrm{HH}$, however, used alone, they are not able to change behaviors. The same thing happens with the component related to the distribution of reminders and posters at the health care site $\mathrm{e}^{(19,21,30,32,34)}$.

In this element, it is worth mentioning the proposal made by Farhoudi et al. ${ }^{(4)}$, who chose to use colorful posters, in different sizes, similar to cartoons or comics that were changed monthly in order to attract the attention of health professionals. This strategy favored $\mathrm{HH}$ compliance, which was $29.8 \%$ to $71 \%$ after one year. Although the study did not provide information on how the cleanings were made, it is important to note that these should be cleanable and preserved, and the material should favor this technique, thus avoiding an effect contrary to the desired ${ }^{(45)}$.

With regard to greater sustainability over time in $\mathrm{HH}$ compliance, interventions that presented educational actions that included the five components of the multimodal strategy maintained higher post-intervention compliance rates $\mathrm{s}^{(7,8,13,24-25,27,36)}$. The self-sustaining average among these studies was $83 \%$, and some factors, besides those related to infrastructure, can be considered as responsible for such results, such as intervention time, which ranged from three months to one year or more, lectures and workshops used concomitantly by means of practical elucidations, immediate and/or weekly feedback, monthly reports to team leaders and managers, professional effort recognition, placards at strategic locations, screenshots on computers, and institution's commitment to security environment.

It should be emphasized that health education has been shown to be effective in rising and maintaining $\mathrm{HH}$ compliance rates, as long as it allows for a re-signification of behaviors and assimilation of relevant information. Thus, innovative methods must replace conservative behaviors, in order to recognize the health professional as an active subject of his work process and to question reasons for non-compliance that transcend the domain of the individual and pass through structural, organizational, educational and management components.

\section{Study limitations}

The limitations of this review consider that some included studies do not present in detail the strategies implemented, such as time of intervention and evaluation after intervention, whose analysis may present subjectivity and information gaps. However, all data from the included surveys were collected from the direct observation by means of a validated instrument recommended by the World Health Organization, which is considered the gold standard when it is desired to verify compliance ${ }^{(37)}$, but which are subject to to the Hawthorne effect.

\section{Contributions for the sectors of Health and Nursing}

The results of the present study are important because they portray the setting about the effectiveness of the implementation of the multimodal strategy to improve $\mathrm{HH}$ through the descriptive analysis of its contemplated elements and sustainability of results over time. This review brought together some of the strategic actions developed and used in different countries and institutions that have proven to be effective for $\mathrm{HH}$ compliance, which may help in the planning and implementation of health education in the context of the theme, since $\mathrm{HH}$ compliance is a global challenge, with serious negative repercussions for patient safety and the quality of health services offered.

\section{CONCLUSION}

The implementation of the multimodal strategy proved to be effective for improving $\mathrm{HH}$ compliance and sustainability over time, especially when all five components of the intervention were used in an appropriate, articulated and interdependent manner. The results suggest that the use of isolated elements, such as the change in infrastructure or distribution of educational posters or punctual health education is not enough to guarantee $\mathrm{HH}$ compliance. Likewise, important elements should be considered in the planning and execution of said strategy to increase $\mathrm{HH}$ and ensure its sustainability, such as the involvement and commitment of management with security actions, individual and/or collective feedback and the use of active and permanent methodologies 
for health education. In this context, the achievement and dissemination of study results through multicomponent intervention is encouraged as a way to identify successful approaches, looking for possible implementation adequacy and continuous improvements in health care environments.

\section{ACKNOWLEDGMENT}

We would like to thank the Technical Course in Nursing and the Escola Técnica de Saúde da Universidade Federal de Uberlândia (ESTES-UFU) for the support to the publication of this paper.

\section{REFERENCES}

1. World Health Organization (WHO). A Guide to the Implementation of the WHO Multimodal Hand Hygiene Improvement Strategy. Geneva: WHO; 2009. 48p.

2. Agência Nacional de Vigilância Sanitária (BR). Assistência Segura: uma reflexão teórica aplicada à prática. Brasília: Anvisa; 2017. 171p. (Série Segurança do Paciente e Qualidade em Serviços de Saúde).

3. Storr J, Twyman A, Zingg W, Damani N , Kilpatrick C, Reilly J, et al. Core components for effective infection prevention and control programmes: new WHO evidence-based recommendations. Antimicrob Resist Infect Control. 2017;6:6. doi: https://doi.org/10.1186/ s13756-016-0149-9

4. Farhoudi F, Dashti AS, Davani MH, Ghalebi N, Sajadi G, Taghizadeh R. Impact of WHO hand hygiene improvement program implementation: a quasi-experimental trial. Biomed Res Int. 2016;2016. doi: http://dx.doi.org/10.1155/2016/7026169

5. Arntz PRH, Hopman J, Nillesen M, Yalcin E, Bleeker-Rovers CP, Voss A, et al. Effectiveness of a multimodal hand hygiene improvement strategy in the emergency department. Am J Infect Control [Internet]. 2016 [cited 2017 Jun 12];44(11)1203-07. Available from: http://dx.doi. org/10.1016/j.ajic.2016.03.017

6. Pittet D. Hand Hygiene: from research to action. J Infect Prev. 2017;18(3):100-2. doi: https://doi.org/10.1177/1757177417705191

7. Fariñas-Alvarez C, Portal-María T, Flor-Morales V, Aja-Herrero A, Fabo-Navarro M, Lanza-Marín S, et al. Estrategia multimodal para la mejora de la adherencia a la higiene de manos en un hospital universitario. Rev Calidad Asist [Internet]. 2017 [cited 2017 Jul 02];32(1),50-6. Available from: http://dx.doi.org/10.1016/j.cali.2016.06.011

8. Visan FA, Zakaria A, Castro J, Alhasanat O, Ismail KA, Ansari NA, et al. SWITCH: Al Wakra Hospital Journey to $90 \%$ Hand Hygiene Practice Compliance, 2011-2015. BMJ Qual Improv Rep [Internet]. 2017 [cited 2017 Sep 05];6(1). Available from: http://dx.doi.org/10.1136/ bmjquality.u211699.w4824

9. Graveto JMGN, Rebola R, Fernandes E, Costa PS. Higiene das mãos: adesão dos enfermeiros após processo formativo. Rev Bras Enferm. 2018;71(3):1189-93. doi: http://dx.doi.org/10.1590/0034-7167-2017-0239

10. Belela-Anacleto ASC, Peterlini MAS, Pedreira MLG. Hand hygiene as a caring practice: a reflection on professional responsibility. Rev Bras Enferm. 2017;70(2):442-5. doi: http://dx.doi.org/10.1590/0034-7167-2016-0189

11. Marra AR, Edmond MB. New technologies to monitor healthcare worker hand hygiene. Clin Microbiol Infect. 2014;20(1):29-33. doi: http:// dx.doi.org/10.1111/1469-0691.12458

12. Kingston $\mathrm{L}, \mathrm{O}^{\prime} \mathrm{C}$ (nnell NH, Dunne CP. Hand hygiene-related clinical trials reported since 2010: a systematic review. J Hosp Infect. 2016;92(4):309-20. doi: http://dx.doi.org/10.1016/j.jhin.2015.11.012

13. Leblebicioglu H, Koksal I, Rosenthal VD, Akan OA, Ozgultekin A, Kendirli T, et al. Impact of the International Nosocomial Infection Control Consortium (INICC) multidimensional hand hygiene approach, over 8 years, in 11 cities of Turkey. J Infect Prev [Internet]. 2015 [cited 2017 Jul 02];16(4):146-54. Available from: http://dx.doi.org/10.1177/1757177414560249

14. Waltz C, Strickland OL, Lenz E. Measurement in nursing research. $4^{\mathrm{a}}$ ed. New York: Hardcover; 2010. 540p.

15. Mendes KDS, Silveira RCCP, Galvão CM. Revisão integrativa: método de pesquisa para a incorporação de evidências na saúde e na enfermagem. Texto Contexto Enferm. 2008;17(4):758-64. doi: http://dx.doi.org/10.1590/S0104-07072008000400018

16. Soares CB, Hoga LAK, Peduzzi M, Sangaleti C, Yonekura T, Silva D. Integrative review: concepts and methods used in nursing. Rev Esc Enferm USP. 2014;48(2):335-45. doi: http://dx.doi.org/10.1590/S0080-6234201400002000020

17. Santos CMC, Pimenta CAM, Nobre MRC. The PICO strategy for the research question construction and evidence search. Rev Latino-Am Enfermagem. 2007;15:508-11. doi: http://dx.doi.org/10.1590/S0104-11692007000300023

18. Mathai AS, George SE, Abraham J. Efficacy of a multimodal intervention strategy in improving hand hygiene compliance in a tertiary level intensive care unit. Indian J Crit Care Med [Internet]. 2011 [cited 2017 May 17];15(1):6-15. Available from: http://dx.doi. org/10.4103/0972-5229.78215

19. Borges LFA, Rocha LA, Nunes MJ, Gontijo Filho PP. Low compliance to handwashing program and high nosocomial infection in a Brazilian hospital. Interdiscip Perspect Infect Dis [Internet]. 2012 [cited 2017 May 12];2012:579-681. Available from: http://dx.doi.org/ $10.1155 / 2012 / 579681$

20. Mestre G, Berbel C, Tortajada P, Alarcia M, Coca R, Gallemi G, et al. "The 3/3 Strategy": a successful multifaceted hospital wide hand hygiene intervention based on WHO and Continuous Quality Improvement Methodology. PLoS ONE [Internet]. 2012 [cited 2017 Jun 17];7(10). 
Available from: https://doi.org/10.1371/journal.pone.0047200

21. Mazi W, Senok AC, Al-Kahldy S, Abdullah D. Implementation of the world health organization hand hygiene improvement strategy in critical care units. Antimicrob Resist Infect Control [Internet]. 2013[cited 2017 May 17];2(1):15. Available from: http://dx.doi. org/10.1186/2047-2994-2-15

22. Schmitz K, Kempker RR, Tenna A, Stenehjem E, Abebe E, Tadesse L, et al. Effectiveness of a multimodal hand hygiene campaign and obstacles to success in Addis Ababa, Ethiopia. Antimicrob Resist Infect Control [Internet]. 2014 [cited 2017 Jun 23];3(1):8. Available from: http://dx.doi.org/10.1186/2047-2994-3-8

23. Restrepo AV, Valderrama MP, Correa AL, Mazo LM, González NE, Jaimes F. Implementación de la estrategia "Atención Limpia es Atención Segura" en un hospital de tercer nivel en Medellín, Colombia. Rev Chil Infectol [Internet]. 2014 [cited 2017 May 05];31(3):280-6. Available from: http://dx.doi.org/10.4067/S0716-10182014000300005

24. Mahfouz AA, Al-Zaydani IA, Abdelaziz AO, El-Gamal MN, Assiri AM. Changes in hand hygiene compliance after a multimodal intervention among health-care workers from intensive care units in Southwestern Saudi Arabia. J Epidemiol Glob Health [Internet]. 2014 [cited 2017 Jun 18];4(4):315-21. Available from: http://dx.doi.org/10.1016/j.jegh.2014.05.002

25. Chen JK, Wu KS, Lee SS, Lin HS, Tsai HC, Li CH, et al. Impact of implementation of the World Health Organization multi modal hand hygiene improvement strategy in a teaching hospital in Taiwan. Am J Infect Control [Internet]. 2016 [cited 2017 Jun 20];44(2):222-7. Available from: http://dx.doi.org/ 10.1016/j.ajic.2015.10.004

26. Sakihama T, Honda H, Saint S, Fowler KE, Kamiya T, Sato Y, et al. Improving healthcare worker hand hygiene adherence before patient contact: A multimodal intervention of hand hygiene practice in three Japanese tertiary care centers. J Hosp Med [Internet]. 2016 [cited 2017 Jun 10];11(3):199-205. Available from: http://dx.doi.org/10.1002/jhm.2491

27. Patel B, Engelbrecht H, McDonald H, Morris V, Smythe W. A multifaceted hospital-wide intervention increases hand hygiene compliance. S Afr Med J [Internet]. 2016 [cited 2017 Aug 12];106(4):32-5. Available from: http://dx.doi.org/10.7196/SAMJ.2016.v106i4.10671

28. Trannin KP, Campanharoz CRV, Lopes MCBT, Okuno MFP, Batista REA. Adesão à higiene das mãos: intervenção e avaliação. Cogitare Enferm [Internet]. 2016 [cited 2017 Aug 12];21(2):1-7. Available from: http://ojs.c3sl.ufpr.br/ojs2/index.php/cogitare

29. Mu X, Xu Y, Yang T, Zhang J, Wang C, Liu W, et al. Improving hand hygiene compliance among healthcare workers: an intervention study in a Hospital in Guizhou Province, China. Braz J Infect Dis [Internet]. 2016 [cited 2017 Jul 15];20(5)413-8. Available from: http://dx.doi.org/ 10.1016/j.bjid.2016.04.009

30. O'Donoghue M, Ng SH, Suen LK, Boost M. A quasi-experimental study to determine the effects of a multifaceted educational intervention on hand hygiene compliance in a radiography unit. Antimicrob Resist Infect Control [Internet]. 2016 [cited 2017 Jul 20];5:36. Available from: http://dx.doi.org/10.1186/s13756-016-0133-4

31. Moghnieb R, Soboh R, Abdullah D, El-Helou M, Al Hassan S, Ajjour L, et al. Health workers' compliance to the My 5 Moments for Hand Hygiene: comparison of 2 interventional methods. Am J Infect Control [Internet]. 2017 [cited 2017 Aug 20];45(1):89-91. Available from: http://dx.doi.org/10.1016/j.ajic.2016.08.012

32. Pfäfflin F, Tufa TB, Getachew M, Nigussie T, Schönfeld A, Häussinger D, et al. Implementation of the WHO multimodal hand hygiene improvement strategy in a university hospital in Central Ethiopia. Antimicrob Resist Infect Control [Internet]. 2017 [cited 2017 Sep 20];6:3. Available from: http://dx.doi.org/10.1186/s13756-016-0165-9

33. Santosaningsih D, Erikawati D, Santoso S, Noorhamdani N, Ratridewi I, Candradikusuma D, et al. Intervening with healthcare workers, hand hygiene compliance, knowledge, and perception in a limited-resource hospital in Indonesia: a randomized controlled trial study. Antimicrob Resist Infect Control [Internet]. 2017 [cited 2017 Aug 10];6:23. Available from: http://dx.doi.org/10.1186/s13756-017-0179-y

34. Pereira EBS, Jorge MT, Oliveira EJ, Ribeiro Jr AL, Santos LR, Mendes-Rodrigues C. Evaluation of the Multimodal Strategy for Improvement of Hand Hygiene as Proposed by the World Health Organization. J Nurs Care Qual [Internet]. 2017 [cited 2017 Sep 12];32(2):1 1-9. Available from: http://dx.doi.org/10.1097/NCQ.0000000000000197

35. Shen L, Wang X, An J, Zhou N, Sun L, Liu X. Implementation of WHO multimodal strategy for improvement of hand hygiene: a quasiexperimental study in a traditional Chinese medicine hospital in Xian, China. Antimicrob Resis Infect Contr [Internet]. 2017 [cited 2017 Sep 23];6:98. Available from: http://dx.doi.org/10.1186/s13756-017-0254-4

36. Kuwaiti AA. Impact of a multicomponent hand hygiene intervention strategy in reducing infection rates at a university hospital in Saudi Arabia. Int Med Appl Sci [Internet]. 2017 [cited 2017 Jun 12];9(3):137-43. Available from: http://dx.doi.org/10.1556/1646.9.2017.24

37. Musu M, Finco G, Mura P, Landoni G, Piazza MF, Messina M, et al. Controlling catheter-related bloodstream infections through a multi-centre educational programme for intensive care units. J Hosp Infect [Internet]. 2017 [cited 2017 Aug 12];97(3):275-81. Available from: http:// dx.doi.org/10.1016/j.jhin.2017.08.010

38. Organização Pan-Americana da Saúde-OPAS. Agência Nacional de Vigilância Sanitária. Manual para observadores: estratégia multimodal da OMS para a melhoria da higienização das mãos. Brasília: Ministério da Saúde. 2008. 58p.

39. Allegranzi B, Gayet-Ageron A, Damani N, Bengaly L, McLaws ML, Moro ML, et al. Global implementation of WHO's multimodal strategy for improvement of hand hygiene: a quasi-experimental study. Lancet Infect Dis [Internet]. 2013 [cited 2017 May 23];13(10):843-51. Available from: http://dx.doi.org/10.1016/S1473-3099(13)70163-4

40. Ministério da Saúde (BR). Agência Nacional de Vigilância Sanitária. Agenda Nacional de Prioridades de Pesquisa em Vigilância Sanitária: Núcleo de Educação, Pesquisa e Conhecimento. Brasília (DF): Ministério da Saúde, 2015. 
41. United Nations Development Programme-UNDP. Human Development Report 2016: Human Development for Everyone. New York: Oxford University Press; 2016. 272p.

42. Ministério da Saúde (BR). Secretaria de Gestão do Trabalho e da Educação na Saúde. Departamento de Gestão da Educação em Saúde. Política nacional de educação permanente em saúde. Brasília: Ministério da Saúde. 2009. 64p.

43. Bandura A. A evolução da teoria social cognitiva. In: Bandura A, Azzi RG, Polydoro SAJ. Teoria social cognitiva: conceitos básicos. Porto Alegre: Artmed; 2008.

44. Crouzet T. O gesto que salva. Paris: Createspace; 2014.

45. Ministério da Saúde (BR). Agência Nacional de Vigilância Sanitária (ANVISA). Segurança do paciente em serviços de saúde: limpeza e desinfecção de superfícies. Brasília: Anvisa; 2012. 118p. 